\title{
Factors Affecting the Outcome of Surgical Versus Nonsurgical Treatment of Cervical Radiculopathy
}

\author{
Markus Engquist, Hakan Lofgren, Birgitta Öberg, Anders Holtz, Anneli Peolsson,
} Anne Soderlund, Ludek Vavruch and Bengt Lind

\section{Linköping University Post Print}

\section{Tweet}

N.B.: When citing this work, cite the original article.

Original Publication:

Markus Engquist, Hakan Lofgren, Birgitta Öberg, Anders Holtz, Anneli Peolsson, Anne Soderlund, Ludek Vavruch and Bengt Lind, Factors Affecting the Outcome of Surgical Versus Nonsurgical Treatment of Cervical Radiculopathy, 2015, Spine, (40), 20, 1553-1563. http://dx.doi.org/10.1097/BRS.0000000000001064

Copyright: Lippincott, Williams \& Wilkins

http://www.lww.com/

Postprint available at: Linköping University Electronic Press

http://urn.kb.se/resolve?urn=urn:nbn:se:liu:diva-125695 
Factors affecting the outcome of surgical versus nonsurgical treatment of cervical radiculopathy - a prospective, randomized study

Markus Engquist, $M D^{1}$; Håkan Löfgren, MD, PhD²; Birgitta Öberg, PhD, RPT ${ }^{3}$; Anders Holtz, MD, PhD ; Anneli Peolsson, PhD, RPT ${ }^{3}$; Anne Söderlund PhD, RPT ${ }^{5}$; Ludek Vavruch, MD, $P h D^{2} ;$ Bengt Lind, $M D, P h D^{6}$

${ }^{1}$ Department of Orthopaedics, Ryhov Hospital, Sweden and Department of Orthopaedics, Institute of Clinical Sciences at Sahlgrenska Academy, University of Gothenburg, Sweden ${ }^{2}$ Neuro-Orthopedic Center, Ryhov Hospital, Jönköping, Sweden

${ }^{3}$ Department of Medical and Health Sciences, Division of Physiotherapy, Faculty of Health Sciences, Linköping University, Linköping, Sweden

${ }^{4}$ Department of Neuroscience, Neurosurgery, Uppsala University Hospital, Uppsala, Sweden

${ }^{5}$ Department of Physiotherapy, School of Health, Care and Social Welfare, Mälardalen University, Västerås, Sweden

${ }^{6}$ Department of Orthopaedics, Institute of Clinical Sciences at Sahlgrenska Academy, University of Gothenburg, Sweden and Spine Center Göteborg, Gothenburg, Sweden

\section{Corresponding author:}

Markus Engquist, MD

Address: Department of Orthopaedics, Ryhov Hospital, S-551 85 Jönköping, Sweden.

Phone: +46-36-321514

Fax: +46 36321506

E-mail: markus.engquist@lj.se 


\section{Acknowledgements}

The study was financially supported by the Medical Research Council of Southeast Sweden. The work of Markus Engquist was financially supported by Futurum - the Academy for Health and Care, Jönköping County Council. We would like to thank university statistician Henrik Magnusson for statistical support and Bo Sigstedt M.D, PhD for radiological evaluation.

\section{Research Ethics Committee Approval}

The study was approved by the Regional Ethical Review Board at the Faculty of Health Sciences in Gothenburg, and the experiments complied with the current laws of Sweden (Dnr S 222-02). 


\section{Abstract}

\section{Study Design}

Prospective randomized controlled trial.

\section{Objective}

To analyze factors that may influence the outcome of anterior cervical decompression and fusion (ACDF) followed by physiotherapy versus physiotherapy alone for treatment of patients with cervical radiculopathy.

\section{Summary of Background Data}

An understanding of patient-related factors affecting the outcome of ACDF is important for preoperative patient selection. No previous prospective, randomized study of treatment effect modifiers relating to outcome of ACDF compared with physiotherapy has been carried out.

\section{Methods}

Sixty patients with cervical radiculopathy were randomized to ACDF followed by physiotherapy or physiotherapy alone. Data for possible modifiers of treatment outcome at one year, such as sex, age, duration of pain, pain intensity, disability (Neck Disability Index, NDI), patient expectations of treatment, anxiety due to neck/arm pain, distress (Distress And Risk Assessment Method, DRAM), self efficacy (Self Efficacy Scale, SES) health status (EQ5D) and MRI findings were collected. A multivariate analysis was performed to find treatment effect modifiers affecting the outcome regarding arm/ neck pain intensity and NDI. 


\section{Results}

Factors that significantly altered the treatment effect between treatment groups in favor of surgery were: duration of neck pain $<12$ months ( $p=0.007)$, duration of arm pain $<12$ months ( $p=0.01)$ and female sex $(p=0.007)$ (outcome: arm pain), low EQ-5D index (outcome: neck pain, $p=0.02$ ), high levels of anxiety due to neck/arm pain (outcome: neck pain, $p=0.02$ and NDI, $p=0.02)$, low SES score $(p=0.05)$ and high DRAM score $(p=0.04)$. (outcome: NDI). No factors were found to be associated with better outcome with physiotherapy alone.

\section{Conclusions}

In this prospective, randomized study of patients with cervical radiculopathy, short duration of pain, female sex, low health quality, high levels of anxiety due to neck/arm pain, low self efficacy and a high level of distress before treatment were associated with better outcome from surgery. No factors were found to be associated with better outcome from physiotherapy alone. 


\section{Key Words}

Cervical radiculopathy, randomized, RCT, physiotherapy, surgery, ACDF, outcome, cervical disc degeneration, predictors, treatment effect modifier.

\section{Key Points}

- This prospective, randomized study of cervical radiculopathy examined possible treatment effect modifiers related to outcome of anterior cervical decompression and fusion followed by physiotherapy versus physiotherapy alone.

- Short duration of pain, female sex, low health status, high levels of anxiety due to neck/arm pain, low self efficacy and a high level of distress were associated with better outcome from surgery.

- $\quad$ Age, smoking, preoperative pain levels, type of disc herniation and level of depression did not affect the outcome between surgical and nonsurgical treatment.

- No factors were found to be associated with better outcome from physiotherapy alone.

- Gender, high distress and/ or anxiety levels or a poor health status should not disqualify patients from surgical treatment. A better treatment outcome can be expected when surgery, if needed, is performed within a year from the onset of CR symptoms

\section{Mini Abstract/ Précis}

This prospective, randomized study of surgical versus nonsurgical treatment of cervical radiculopathy examined treatment effect modifiers for surgical or nonsurgical success. Female sex, short duration of pain, low EQ-5D, high DRAM-score, low self efficacy and high levels of anxiety due to neck/arm pain were associated with better outcome from surgery. 


\section{Introduction}

Previously reported data from this prospective randomized study of surgical versus nonsurgical treatment of cervical radiculopathy showed that surgery was more effective at one year follow-up with regard to the outcome measures neck pain intensity and patients' global assessment. ${ }^{1}$ The differences between the groups decreased over time and after two years, the only significant difference was in neck pain intensity No significant differences were found for disability or arm pain intensity. To further improve patient selection and thereby surgical outcome, an understanding of patient-related factors that could potentially influence the results is crucial.

No prior prospective randomized studies evaluating treatment effect modifiers for the outcome of surgical versus nonsurgical treatment have been carried out. Factors that have been suggested as having a positive influence on outcome within a group of surgically treated patients include: high preoperative disability and pain levels, ${ }^{2-3}$ male sex, ${ }^{4-5}$ nonsmokers, ${ }^{4-6}$ low preoperative disability and pain, ${ }^{4-5}$ high age, ${ }^{2,4}$ normal preoperative sensory function, ${ }^{2}$ and normal score on the Distress and Risk Assessment Method (DRAM). ${ }^{6}$ Conversely, there are also reports of no correlation between treatment effect and sex, age, number of levels fused, disc level fused, or duration of preoperative symptoms. ${ }^{3}$ However, no randomized comparisons have been made with a nonsurgically treated group and these studies can therefore only address differences within a group of operated patients, but not cases in which surgery would have been more successful than nonsurgical treatment, or vice versa. Since the natural history of cervical radiculopathy has been reported to be favorable, ${ }^{7}$ the real challenge for the surgeon is to identify factors to help select patients who will benefit from surgery, since many patients may do just as well, or perhaps even better, without surgery.

In this prospective, randomized study we carry out the first sub-analysis of factors that may influence outcome for patients who undergo surgical versus nonsurgical treatment for cervical radiculopathy. We also describe the baseline characteristics of this patient group. 


\section{Material and methods}

\section{Study design and patient population}

Originally, 63 patients were included in the study, as described earlier. ${ }^{1}$ The present study consisted of the 60 patients who completed the 12 month follow-up (3 patients didn't return the questionnaires within the stipulated time span of $\pm 10 \%)$. Participants were randomized into either of two groups: anterior cervical decompression and fusion (ACDF) followed by physiotherapy (PT), or the same PT program alone. Overall results at 6, 12, and 24 months between the two treatment groups regarding pain intensity, disability, physical function and use of analgesics were reported in two earlier papers. ${ }^{1,8}$ Inclusion criteria were pain (with or without sensory and/or motor deficit) in one or both arms indicating nerve root involvement, caused by disc herniation with or without osteophytes, or stenosis caused by osteophytes, confirmed by MRI, duration of symptoms eight weeks to five years, symptoms involving one or two disc levels, and age 18-65 years.

Exclusion criteria were myelopathy, history of neck distortion (Whiplash Associated Disorder) or "generalized" muscle-pain (i.e. fibromyalgia), indication for different type of cervical spine surgery (i.e. vertebral body resection or foraminotomy), malignancy, inflammatory joint disease, psychiatric disorder, concurrent work-disabling disease, other spinal disease causing pain or neurologic deficit during the last year or prior cervical spine surgery. After agreeing to participate in the study and signing the informed consent, patients completed baseline questionnaires. A secretary at one of the centers then randomized the patients into one of the two treatment groups, using equal numbers of randomly distributed sealed envelopes. A group of 37 patients who declined participation in the study because they did not want to be randomized, but who did complete the baseline questionnaire, was also analyzed to detect possible differences in treatment effect modifiers between these patients and the participants at baseline.

\section{Treatment}




\section{Surgical group $(n=30)$}

One of four participating senior surgeons performed anterior cervical decompression and fusion on the patients. The disc and osteophytes were removed and the segment or segments fused. For one-level fusion $(n=26)$, a cylindrical titanium implant $(B A K / C \circledR$, Zimmer, Minneapolis, MN, USA) filled with autologous bone collected during decompression and bone bed preparation was used. For two-level fusion $(n=4)$, two Trabecular Metal cages were used, along with an anterior plate to achieve primary stability. No iliac crest grafts or other bone substitutes were used. Three months after surgery, the patients initiated the same physiotherapy program as those in the nonsurgical group. The program was then continued for a minimum of three months. The three-month time span prior to physiotherapy was chosen to allow healing of the fusion. Following the absence of movement between fused segments on flexion-extension radiographs, all segments were considered being fused at the 3-month follow-up visit with the surgeon.

\section{Nonsurgical group $(n=30)$}

Physiotherapy was individualized based on a three-step program. The treatment each patient received was recorded. Step one consisted of neck exercises and procedures for pain relief. Step two involved general exercises, and step three involved pain coping strategies, increasing self-efficacy and stress management strategies. The patient carried out the exercise program daily at home and twice a week in the clinic for a minimum of three months. A more detailed description of the program has previously been published. ${ }^{9}$ No restrictions or changes in the use of medication were stipulated by the study protocol in any of the treatment groups.

\section{Evaluation}

The baseline questionnaires were filled in before randomization. For the present study, the 12-month follow-up carried out by an unbiased observer was chosen as the endpoint. The 
reason for not choosing the 24-month follow-up was to avoid the effects of patients crossing over to surgical treatment. At the 12-month follow-up, only one patient originally randomized to nonsurgical treatment had been operated (at patient's own request, due to persistent pain), compared with five at the 24-month follow-up. ${ }^{1}$ The data for the patient who crossed over were kept in the nonsurgical group. Moreover, the 12-month follow-up showed the greatest differences in treatment effect between groups, thereby improving the chance of finding treatment effect modifiers.

Outcome measures included self-reported disability (Neck Disability Index, NDI) ${ }^{9-10}$ (score percent 0-100) and self-reported pain intensity, which was registered on a horizontal visual analogue scale (VAS) 0-100 mm, where 0 was characterized as "no pain" and 100 as "worst pain imaginable". Neck pain and arm pain were registered separately.

\section{Treatment effect modifiers}

Twenty-four possible modifiers of treatment outcome were chosen from the baseline data: sex, age, smoking, duration of pain and intensity (visual analogue scale (VAS) 0-100) for neck and arm separately, arm/neck pain ratio, NDI, patient expectations of treatment, and potential to return to work. Patients also completed a "symptom index" questionnaire that included shoulder pain, back pain, headache, hand numbness, hand weakness, sleeping problems, and anxiety due to neck/arm pain, which could be answered with "never," "occasionally," "every day," or "always." For the purposes of analysis, the answers were dichotomized into two groups: never/occasionally or every day/always. The question regarding patient expectations of returning to work within 6 months after treatment start could be answered with "very high," "high," "neither high nor low," "low," or "very low." The answers were dichotomized into two groups where "very high/high" was scored as "high" and the other answers as "low." Patient expectations for treatment effect were scored as "full recovery", "relief", "improvement" or "no expectations", and dichotomized into "full recovery" or "relief/ improvement/no expectations." 
Health and psychological parameters included: the EuroQol Five Dimensions Questionnaire (EQ-5D-3L) (index -0.584-1), ${ }^{11}$ the EuroQol EQ-VAS (VAS 0-100), ${ }^{11}$ the Zung depression scale (score 0-69), ${ }^{12}$ the Self-Efficacy Scale (SES) (score 0-200), ${ }^{13}$ and the Distress and Risk Assessment Method (DRAM).${ }^{14}$ Disc herniation/stenosis was graded by an unbiased senior radiologist as "soft" or "bony/combined." Continuous variables were converted into categorical variables as follows: NDI, age and SES split by the median, pain intensity and EQ-5D split into two equal parts (since the different scales have different medians), duration of pain of more or less than 12 months, DRAM, and Zung in established groups. ${ }^{12,13}$

\section{Statistics}

For the comparison of baseline data between participators and non-participators the independent samples t-test was used on parametric data and the Fischer's exact test or Chisquare test on non-parametric data. Results are presented in table 1.

For the main analysis, change between baseline and 12 months was calculated, and defined as treatment effect (TE), for the three outcome measures; NDI, arm pain, and neck pain. Difference in TE was assessed with the fixed factor surgical or nonsurgical treatment. Separate two-way, full-factorial ANOVAs on each outcome measure were analyzed, using treatment plus one additional variable as fixed factors. The two-way interaction between treatment and the additional variable was defined and interpreted as a treatment effect modifier (TEM) if the interaction effect was significant. In addition, estimated marginal means were calculated on the interaction effect to analyze the treatment effect difference within each TEM group. A positive value is in favor of surgery and a negative value is in favor of nonsurgical treatment. The results from the TEM and the estimated marginal means are presented in table 2-4. All analyses were two-sided and the significance level was set at $\mathrm{p}<0.05$. 


\section{Results}

The only significant difference at baseline between the two treatment groups was that the patients in the surgical group were older, with a mean difference of 4.7 years $(p=0.04)$. Table 1 presents the baseline characteristics of the treated patient population and the nonparticipants. Participants had significantly less intense neck and arm pain, and longer duration of neck pain than non-participants. No significant differences were found for the other treatment effect modifiers compared with non-participants.

In the last 12 months before inclusion in the study, $70 \%$ of the patients had visited another physician, $50 \%$ a physiotherapist and $18 \%$ a chiropractor due to cervical radiculopathy. Of these, none experienced relief of symptoms from treatment given by the physician, $20 \%$ experienced relief from treatment given by the physiotherapist and 36\% from treatment given by the chiropractor. All patients, however, had sufficient residual symptoms to be referred for surgical decision.

Tables 2-4 present the results for treatment effect modifiers in relation to each outcome measure separately. All sub-parts of each analyzed parameter consisted of at least $22 \%$ of the total patient population for trichotomized parameters and $26 \%$ for dichotomized parameters, except for type of disc herniation, where only $12 \%$ of the total population was in the "soft" group, due to a skewed distribution and a relatively high number of missing values.

Factors that significantly altered the TE between treatment groups in favor of surgery $(p<0.05)$ were: duration of neck pain $<12$ months (outcome measure: arm pain, $p=0.007$ ); duration of arm pain < 12 months (outcome measure: arm pain, $p=0.01$ ); female sex

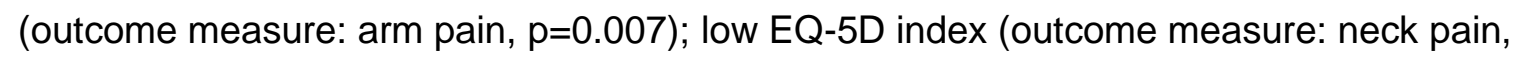
$p=0.02$ ); high levels of anxiety due to neck/arm pain (outcome measure: neck pain, $p=0.02$ and NDI, p=0.02); low SES score (outcome measure: NDI, $p=0.05$ ) and high DRAM score (outcome measure: NDI, $\mathrm{p}=0.04)$. 
Other trends that favored surgery $(p<0.1)$ included: frequent headaches (outcome measure: arm pain, $p=0.05$ ); frequent hand numbness (outcome measure: arm pain, $p=0.06$ ); frequent shoulder pain (outcome measure: arm pain, $p=0.09$ ); duration of neck pain $<12$ months (outcome measure: neck pain, $p=0.07$ ); female sex (outcome measure: NDI, $p=0.09$ ). Factors that did not affect outcome included age, smoking, type of disc herniation, preoperative pain levels and depression according to the Zung scale. 


\section{Discussion}

The present study identified certain factors that may be of importance in the selection of patients for surgical treatment for cervical radiculopathy. The effect of surgical treatment for arm pain was better among patients with short duration of symptoms ( $<12$ months). This could indicate that the potential for compromised nerves to recover from compression may diminish with time, which may be a factor to consider when scheduling surgical procedures. Similar findings have been seen in lumbar disc surgery. ${ }^{15-16}$ Treatment effect on neck pain was not affected by duration of pain, suggesting that the effect of fusion on nociceptive pain can still be achieved after a longer periods of symptom duration. Trends $(p=0.05-0.09)$ were also seen suggesting that the effect of surgery on arm pain was better among patients with frequent headaches, shoulder pain, and hand numbness - symptoms often associated with cervical radiculopathy - though no far-reaching conclusions should be drawn from this alone.

Somewhat surprisingly, a high level of anxiety due to arm/neck pain and a high DRAM score were associated with greater improvement in NDI for surgically treated patients. Although the cause is unknown, one possible explanation may be that it is more difficult for the anxious and/or distressed patient to commit to a comprehensive rehabilitation program without the extra "boost" provided by a surgical procedure. It is important to emphasize that this does not mean that patients with high DRAM scores and/or anxiety levels necessarily fared better than those with low scores within the surgical group, since the study focused on the differences between surgery followed by physiotherapy and physiotherapy alone. No significant difference in outcome related to DRAM levels could be detected among operated patients in this study, but the number of patients is small for such an analysis.

When evaluating the modifying effect of the DRAM score on treatment effect, Main et al. ${ }^{14}$ analyzed only 11 surgically treated patients, and the conclusion that patients with high DRAM scores had worse clinical outcomes was reached based on patients treated with "advice with reassurance" or "miscellaneous conservative treatments." When combined with our results, 
this finding indicates that a high score on the DRAM scale should not discourage offering surgical treatment when otherwise indicated. In a study on lumbar spine surgery, ${ }^{17}$ no correlation was found between the DRAM score and surgical outcomes measured with the Oswestry Disability Index, which supports the above conclusion. However, another report indicates that patients in the distressed group fared worse than other patients regarding improvement in disability and pain following lumbar spine surgery. ${ }^{18}$ Both these studies were conducted without a control group of nonsurgically treated patients.

Female sex was also associated with better outcomes from surgery than from nonsurgical treatment, in contrast with earlier reports of better surgical outcomes for men. ${ }^{4-5}$ However, these studies did not focus on the difference between surgically and nonsurgically treated patients, but only on the treatment effects within a surgically treated group. In the present study, no differences in outcome were detected between men and women in the surgical group alone, but men fared significantly better concerning arm pain in the nonsurgically treated group $(p=0.04)$. Thus our study suggests that the difference in TE regarding arm pain between groups favors nonsurgical treatment for men, rather than more favorable surgical outcomes for women. Nevertheless, as a prognostic factor for a better outcome from surgery than from physiotherapy alone, female sex was still positive in this study.

Low baseline score on the EQ-5D index was associated with greater relief of neck pain and low SES score with greater increase of the NDI score in the surgical group than in the nonsurgical group. The reason for this is unclear, but the findings indicate that a low health status and/ or self efficacy should not disqualify patients from surgical treatment for cervical radiculopathy. Since pain is an index parameter in the EQ-5D-index and has evident effect on the possibility to perform the tasks listed in the SES-score, there may also be co-variation with pain levels. High preoperative pain levels have been shown to be a factor indicating 
better outcomes within a surgically treated cohort of radiculopathy patients, ${ }^{3}$ but they did not turn out to be a treatment effect modifier in the present study.

The main limit of this study is the small sample size. Therefore, the possibility of type II errors cannot be ruled out. Moreover, when performing a randomized study of this kind, there is always a risk of selection bias since patients who choose to participate in a randomization process for treatment may differ from those who do not. In the present study, participants experienced longer duration of neck pain and lower levels of neck and arm pain intensity than did non-participants, making a generalization of the results to a population with more severe pain uncertain. The fact that short duration of pain was found to be a factor leading to better surgical outcomes may help explain some of the unexpectedly poor effects on arm pain previously found in the same patient population ${ }^{1}$, since the patients in this study had a mean symptom duration of 15-18 months. However, no differences were found between participants and non-participants regarding psychological, sociodemographic, and health parameters, suggesting that pain levels rather than personal factors influence patient willingness to participate in this kind of a randomization process.

The number of patients in the study is too small to make definitive conclusions of which patients to operate, but a reasonable clinical recommendation is that gender, high distress and/ or anxiety levels or a poor health status should not disqualify patients from surgical treatment. Optimal timing for surgery remains to be determined, ${ }^{19}$ but a better treatment outcome can be expected when surgery, if needed, is performed within a year from the onset of CR symptoms. Due to the rather limited differences in treatment effects between surgically and nonsurgically treated patients, we recommend that physiotherapy treatment should precede any surgical decision, but further studies on the effects of different treatment modalities of physiotherapy are required. 


\section{Conclusions}

In this prospective, randomized study of patients with cervical radiculopathy, short duration of pain, female sex, low health quality, high levels of anxiety due to neck/arm pain, low self efficacy and a high level of distress before treatment were associated with better outcome from surgery. No factors were found to be associated with better outcome from physiotherapy alone. 


\section{References}

1. Engquist $\mathrm{M}$, Lofgren $\mathrm{H}$, Oberg $\mathrm{B}$ et al. Surgery versus nonsurgical treatment of cervical radiculopathy: a prospective, randomized study comparing surgery plus physiotherapy with physiotherapy alone with a 2-year follow-up. Spine (Phila Pa 1976) 2013; 38(20): 1715-1722.

2. Anderson PA, Subach BR, Riew KD Predictors of outcome after anterior cervical discectomy and fusion: a multivariate analysis. Spine (Phila Pa 1976) 2009; 34(2): 161-166.

3. Lied, B, Roenning PA, Sundseth $\mathrm{J}$ et al. Anterior cervical discectomy with fusion in patients with cervical disc degeneration: a prospective outcome study of 258 patients (181 fused with autologous bone graft and 77 fused with a PEEK cage). BMC Surg 2010; 10: 10.

4. Peolsson A, Hedlund R, Vavruch $L$ et al. Predictive factors for the outcome of anterior cervical decompression and fusion. Eur Spine J 2003; 12(3): 274-280.

5. Peolsson, A, Peolsson M. Predictive factors for long-term outcome of anterior cervical decompression and fusion: a multivariate data analysis. Eur Spine J 2008; 17(3): 406-414.

6. Peolsson A, Vavruch L, Oberg B. Predictive factors for arm pain, neck pain, neck specific disability and health after anterior cervical decompression and fusion. Acta Neurochir (Wien) 2006; 148(2): 167-173.

7. Wong JJ, Cote P, Quesnele J et al. The Course and Prognostic Factors of Symptomatic Cervical Disc Herniation with Radiculopathy: A Systematic Review of the Literature. Spine J 2014; 14 (8) 1781-1789

8. Peolsson A, Soderlund A, Engquist M et al. Physical function outcome in cervical radiculopathy patients after physiotherapy alone compared with anterior surgery followed by physiotherapy: a prospective randomized study with a 2-year follow-up. Spine (Phila Pa 1976) 2013; 38(4): 300-307. 
9. Vernon $\mathrm{H}$, Mior S. The Neck Disability Index: a study of reliability and validity. J Manipulative Physiol Ther 1991; 14(7): 409-415.

10. Vernon H. The Neck Disability Index: state-of-the-art, 1991-2008. J Manipulative Physiol Ther 2008; 31(7): 491-502.

11. Brooks R. EuroQol: the current state of play. Health Policy 1996; 37(1): 53-72.

12. Zung WW. A Self-Rating Depression Scale. Arch Gen Psychiatry 1965; 12: 63-70.

13. Altmaier E, Feng RD, Kao C et al. Role of self-efficacy in rehabilitation outcome among chronic low back pain patients. J Counsel Psychol 1993; 40(3): 335-339.

14. Main CJ, Wood PL, Hollis S et al. The Distress and Risk Assessment Method. A simple patient classification to identify distress and evaluate the risk of poor outcome. Spine (Phila Pa 1976) 1992; 17(1): 42-52.

15. Bertalanffy HEH. Clinical long-term results of anterior discectomy without fusion for treatment of cervical radiculopathy and myelopathy. A follow-up of 164 cases. Acta Neurochir (Wien) 1998; 90(3-4): 127-135.

16. Nygaard OP, Romner B, Trumpy JH. Duration of symptoms as a predictor of outcome after lumbar disc surgery. Acta Neurochir (Wien) 1994; 128(1-4):53-6

17. Hobby JL, Lutchman LN, Powell JM et al. (2001). The distress and risk assessment method (DRAM) - failure to predict the outcome of lumbar discectomy. J Bone Joint Surg $\operatorname{Br} 2001 ; 83(1):$ 19-21.

18. Pollock R, Lakkol S, Budithi C et al. (2012). Effect of psychological status on outcome of posterior lumbar interbody fusion surgery. Asian Spine J 2012; 6(3): 178-182.

19. Alentado VJ, Lubelski D, Steinmetz MP, et al. Optimal duration of conservative management prior to surgery for cervical and lumbar radiculopathy: a literature review. Global spine journal 2014;4:279-86. 
Table 1

Baseline data for the 60 study participants and 37 patients who rejected participation but completed the baseline questionnaires.

\begin{tabular}{|l|l|l|l|}
\hline $\begin{array}{l}\text { Treatment effect } \\
\text { modifier }\end{array}$ & $\begin{array}{l}\text { Level at baseline } \\
\text { Mean (SD) }\end{array}$ & $\begin{array}{l}\text { Non-participants } \\
\text { Mean (SD) }\end{array}$ & $\begin{array}{l}\text { P-value } \\
\text { (participants - non- } \\
\text { participants) }\end{array}$ \\
\hline Age & $46(9)$ & $44(7)$ & N.S. \\
\hline $\begin{array}{l}\text { Duration of neck } \\
\text { pain (months) }\end{array}$ & $18(16)$ & $11(9)$ & 0.009 \\
\hline $\begin{array}{l}\text { Duration of arm pain } \\
\text { (months) }\end{array}$ & $15(13)$ & $11(9)$ & N.S. \\
\hline $\begin{array}{l}\text { Neck pain intensity } \\
\text { (VAS 0-100) }\end{array}$ & $49(24)$ & $63(25)$ & 0.009 \\
\hline $\begin{array}{l}\text { Arm pain intensity } \\
\text { (VAS 0-100) }\end{array}$ & $45(24)$ & $61(19)$ & $<0.001$ \\
\hline NDI & $39(14)$ & $43(15)$ & N.S. \\
\hline $\begin{array}{l}\text { Zung depression } \\
\text { scale }\end{array}$ & $24(10)$ & $24(10)$ & N.S. \\
\hline EQ-5D index & $0.52(0.27)$ & $0.44(0.36)$ & N.S. \\
\hline $\begin{array}{l}\text { EQ-VAS } \\
\text { (VAS 0-100) }\end{array}$ & $50(18)$ & $43(23)$ & \\
\hline SES & $131(32)$ & $130(41)$ & \\
\hline
\end{tabular}

Significance was calculated with the independent samples t-test.

\begin{tabular}{|c|c|c|c|c|}
\hline $\begin{array}{l}\text { Treatment effect } \\
\text { modifier (TEM) }\end{array}$ & TEM groups & $\begin{array}{l}\text { Percent at } \\
\text { baseline } \\
(n=63)\end{array}$ & $\begin{array}{l}\text { Non } \\
\text { participants } \\
(\mathrm{n}=37)\end{array}$ & $\begin{array}{l}\text { p-value } \\
\text { (participants } \\
\text { - non- } \\
\text { participants) }\end{array}$ \\
\hline \multirow{2}{*}{ Sex } & Male & 52 & 51 & \multirow{2}{*}{ NS } \\
\hline & Female & 48 & 49 & \\
\hline \multirow{2}{*}{ Smoker } & Yes & 28 & 27 & \multirow{2}{*}{ NS } \\
\hline & No & 72 & 73 & \\
\hline \multirow{3}{*}{ Shoulder pain } & Never/occasionally & 52 & 16 & \multirow{2}{*}{ NS } \\
\hline & Every day/ always & 48 & 84 & \\
\hline & Never/occasionally & 77 & 69 & \\
\hline
\end{tabular}




\begin{tabular}{|c|c|c|c|c|}
\hline Back pain & Every day/ always & 23 & 31 & NS \\
\hline \multirow{2}{*}{ Headache } & Never/occasionally & 90 & 67 & \multirow{2}{*}{ NS } \\
\hline & Every day/ always & 10 & 33 & \\
\hline \multirow{2}{*}{ Hand numbness } & Never/occasionally & 43 & 16 & \multirow{2}{*}{ NS } \\
\hline & Every day/ always & 57 & 84 & \\
\hline \multirow{2}{*}{ Hand weakness } & Never/occasionally & 55 & 32 & \multirow{2}{*}{ NS } \\
\hline & Every day/ always & 45 & 68 & \\
\hline \multirow{2}{*}{ Sleeping problems } & Never/occasionally & 75 & 46 & \multirow{2}{*}{ NS } \\
\hline & Every day/ always & 25 & 54 & \\
\hline \multirow{2}{*}{$\begin{array}{l}\text { Anxiety due to } \\
\text { neck/arm problems }\end{array}$} & Never/occasionally & 92 & 71 & \multirow{2}{*}{ NS } \\
\hline & Every day/ always & 8 & 29 & \\
\hline \multirow{2}{*}{ Work expectations } & High & 56 & 66 & \multirow{2}{*}{ NS } \\
\hline & Low & 44 & 34 & \\
\hline \multirow{2}{*}{$\begin{array}{l}\text { Treatment } \\
\text { expectations }\end{array}$} & Fully recovered & 44 & 41 & \multirow{2}{*}{ NS } \\
\hline & Relief/improved & 56 & 59 & \\
\hline \multirow{2}{*}{$\begin{array}{l}\text { Arm/neck pain ratio } \\
\text { (VAS) }\end{array}$} & Arm pain < neck pain & 42 & 57 & \multirow{2}{*}{ NS } \\
\hline & Arm pain $>$ neck pain & 58 & 43 & \\
\hline \multirow{3}{*}{ DRAM } & Normal & 22 & 24 & \multirow{3}{*}{ NS } \\
\hline & At risk & 58 & 52 & \\
\hline & Distress & 20 & 24 & \\
\hline
\end{tabular}

Significance was calculated with the Chi square test.

Abbreviations: NDI: Neck Disability Index; EQ-5D: EuroQol five dimensions; SES: Self Efficacy Scale; DRAM: Distress and Risk Assessment Method; NS: non significant $(p>0.05)$.

Table 2 
Treatment effects and group comparisons. Outcome: Neck Disability Index (0100) at 12 months.

\begin{tabular}{|c|c|c|c|c|c|}
\hline $\begin{array}{l}\text { Treatment effect } \\
\text { modifier (TEM) }\end{array}$ & TEM groups & $\begin{array}{l}\text { Difference in } \\
\text { treatment } \\
\text { effect } \\
\text { surgery - } \\
\text { non-surgery } \\
(95 \% \mathrm{Cl})\end{array}$ & $\begin{array}{l}P \text { treatment } \\
\text { effect } \\
\text { surgery - } \\
\text { non-surgery }\end{array}$ & $\begin{array}{l}\text { Difference in } \\
\text { treatment } \\
\text { effect } \\
\text { between TEM } \\
\text { groups }\end{array}$ & $\begin{array}{l}P \text { between } \\
\text { TEM groups }\end{array}$ \\
\hline \multirow{2}{*}{ Sex } & Male & $2(-9-13)$ & 0.7 & \multirow{2}{*}{14} & \multirow{2}{*}{0.09} \\
\hline & Female & $16(4-27)$ & 0.01 & & \\
\hline \multirow{2}{*}{ Age } & $18-47$ & $8(-4-19)$ & 0.2 & \multirow{2}{*}{4} & \multirow{2}{*}{0.6} \\
\hline & $48-65$ & $12(-1-24)$ & 0.06 & & \\
\hline \multirow[b]{2}{*}{ Smoker } & No & $10(0-19)$ & 0.05 & \multirow{2}{*}{6} & \multirow{2}{*}{0.6} \\
\hline & Yes & $4(-11-20)$ & 0.6 & & \\
\hline \multirow{2}{*}{$\begin{array}{l}\text { Duration of neck } \\
\text { pain (months) }\end{array}$} & $2-12$ & $14(2-25)$ & 0.02 & \multirow{2}{*}{13} & \multirow{2}{*}{0.1} \\
\hline & $>12$ & $1-11-13)$ & 0.8 & & \\
\hline \multirow{2}{*}{$\begin{array}{l}\text { Duration of arm pain } \\
\text { (months) }\end{array}$} & $2-12$ & $11(1-21)$ & 0.03 & \multirow{2}{*}{7} & \multirow{2}{*}{0.4} \\
\hline & $>12$ & $4(-10-17)$ & 0.9 & & \\
\hline \multirow{2}{*}{$\begin{array}{l}\text { Neck pain intensity } \\
\text { (VAS) }\end{array}$} & $0-49$ & $10(-2-22)$ & 0.09 & \multirow{2}{*}{1} & \multirow{2}{*}{0.9} \\
\hline & $50-100$ & $9(-1-20)$ & 0.07 & & \\
\hline \multirow{2}{*}{$\begin{array}{l}\text { Arm pain intensity } \\
\text { (VAS) }\end{array}$} & $0-49$ & $7(-3-17)$ & 0.2 & \multirow{2}{*}{3} & \multirow{2}{*}{0.7} \\
\hline & $50-100$ & $10(-2-23)$ & 0.09 & & \\
\hline \multirow{2}{*}{ Shoulder pain } & Never/occasionally & $6(-7-20)$ & 0.4 & \multirow{2}{*}{8} & \multirow{2}{*}{0.4} \\
\hline & Every day/ always & $14(5-23)$ & 0.003 & & \\
\hline \multirow{2}{*}{ Back pain } & Never/occasionally & $10(1-20)$ & 0.04 & \multirow{2}{*}{5} & \multirow{2}{*}{0.6} \\
\hline & Every day/ always & $5(-9-20)$ & 0.04 & & \\
\hline \multirow{2}{*}{ Headache } & Never/occasionally & $10(1-19)$ & 0.03 & \multirow{2}{*}{1} & \multirow{2}{*}{1.0} \\
\hline & Every day/ always & $11(-4-25)$ & 0.2 & & \\
\hline \multirow{2}{*}{ Hand numbness } & Never/occasionally & $8(-7-24)$ & 0.3 & \multirow{2}{*}{0} & \\
\hline & Every day/ always & $8(-2-18)$ & 0.1 & & 1.0 \\
\hline & Never/occasionally & $8(-6-22)$ & 0.3 & & \\
\hline Hand weakness & Every day/ always & $8(-2-19)$ & 0.1 & 0 & 1.0 \\
\hline & Soft & $25(-2-52)$ & 0.07 & & \\
\hline $\begin{array}{l}\text { Type of disc } \\
\text { herniation }\end{array}$ & Bony / combined & $13(-1-26)$ & 0.07 & 12 & 0.4 \\
\hline & Never/occasionally & $14(3-25)$ & 0.02 & & \\
\hline
\end{tabular}




\begin{tabular}{|c|c|c|c|c|c|}
\hline Sleeping problems & Every day/ always & $2(9-14)$ & 0.7 & 12 & 0.2 \\
\hline \multirow{2}{*}{$\begin{array}{l}\text { Anxiety due to } \\
\text { neck/arm problems }\end{array}$} & Never/occasionally & $3(-5-12)$ & 0.4 & \multirow{2}{*}{21} & \multirow{2}{*}{$0.02^{\star}$} \\
\hline & Every day/ always & $24(9-39)$ & 0.002 & & \\
\hline \multirow{2}{*}{ Work expectations } & High & $11(0-21)$ & 0.05 & \multirow{2}{*}{1} & \multirow{2}{*}{0.9} \\
\hline & Low & $12(1-23)$ & 0.04 & & \\
\hline \multirow{2}{*}{$\begin{array}{l}\text { Treatment } \\
\text { expectations }\end{array}$} & Fully recovered & $0(-12-12)$ & 1.0 & \multirow{2}{*}{8} & \multirow{2}{*}{0.3} \\
\hline & Relief/improved & $8(-2-19)$ & 0.1 & & \\
\hline \multirow{2}{*}{ NDI at baseline } & $0-40 \%$ & $4(-6-15)$ & 0.4 & \multirow{2}{*}{9} & \multirow{2}{*}{0.3} \\
\hline & $41-100 \%$ & $13(0-25)$ & 0.04 & & \\
\hline \multirow{2}{*}{ Zung } & 0-16 (normal) & $0(-19-18)$ & 1.0 & \multirow{2}{*}{10} & \multirow{2}{*}{0.3} \\
\hline & 17-69 (at risk) & $101-19$ & 0.03 & & \\
\hline \multirow{2}{*}{ EQ-5D index } & $>0.5$ & $4(-7-14)$ & 0.5 & \multirow{2}{*}{12} & \multirow{2}{*}{0.1} \\
\hline & $<0.5$ & $16(4-29)$ & 0.01 & & \\
\hline \multirow{2}{*}{$\begin{array}{l}\text { EQ-VAS } \\
\text { (VAS 0-100) }\end{array}$} & $50-100$ & $7(-4-18)$ & 0.2 & \multirow{2}{*}{2} & \multirow{2}{*}{0.8} \\
\hline & $0-49$ & $9(-4-22)$ & 0.2 & & \\
\hline \multirow{2}{*}{$\begin{array}{l}\text { Arm/neck pain ratio } \\
\text { (VAS) }\end{array}$} & $\begin{array}{l}\text { Arm pain< neck } \\
\text { pain }\end{array}$ & $13(3-23)$ & 0.01 & \multirow[t]{2}{*}{9} & \multirow[t]{2}{*}{0.3} \\
\hline & $\begin{array}{l}\text { Arm pain>neck } \\
\text { pain }\end{array}$ & $4(-7-16)$ & 0.5 & & \\
\hline \multirow{2}{*}{ SES } & $129-200$ & $0(-12-11)$ & 0.9 & \multirow{2}{*}{16} & \multirow{2}{*}{$0.05^{\star}$} \\
\hline & $0-128$ & $16(5-27)$ & 0.006 & & \\
\hline \multirow{3}{*}{ DRAM } & Normal & $0(-18-17)$ & 1.0 & & \multirow{3}{*}{$0.04^{*}$} \\
\hline & At risk & $5(-5-16)$ & 0.3 & & \\
\hline & Distress & $30(12-48)$ & 0.002 & & \\
\hline
\end{tabular}

Treatment effect (TE) is the mean change in the outcome parameter from baseline to12 months

Difference in TE between TEM groups was analyzed with two-way full-factorial ANOVA and difference in treatment effect compared to baseline was analyzed from the estimated marginal means of the same analysis.

* Significant difference between groups $(p<0.05)$ detected.

Abbreviations: NDI: Neck Disability Index; EQ-5D: EuroQol five dimensions; SES:

Self Efficacy Scale; DRAM: Distress and Risk Assessment Method.

Table 3 
Treatment effects and group comparisons. Outcome: neck pain (VAS 0-100) at 12 months.

\begin{tabular}{|c|c|c|c|c|c|}
\hline $\begin{array}{l}\text { Treatment effect } \\
\text { modifier (TEM) }\end{array}$ & TEM groups & $\begin{array}{l}\text { Difference in } \\
\text { treatment } \\
\text { effect } \\
\text { surgery - } \\
\text { non-surgery } \\
(95 \% \mathrm{Cl})\end{array}$ & $\begin{array}{l}P \text { treatment } \\
\text { effect } \\
\text { surgery - } \\
\text { non-surgery }\end{array}$ & $\begin{array}{l}\text { Difference } \\
\text { in treatment } \\
\text { effect } \\
\text { between } \\
\text { TEM groups }\end{array}$ & $\begin{array}{l}P \text { between } \\
\text { TEM groups }\end{array}$ \\
\hline \multirow{2}{*}{ Sex } & Male & $13(-9-35)$ & 0.3 & \multirow{2}{*}{19} & \multirow{2}{*}{0.2} \\
\hline & Female & $32(9-54)$ & 0.006 & & \\
\hline \multirow{2}{*}{ Age } & $18-47$ & $13(-9-35)$ & 0.3 & \multirow{2}{*}{20} & \multirow{2}{*}{0.2} \\
\hline & $48-65$ & $33(9-56)$ & 0.008 & & \\
\hline \multirow{2}{*}{ Smoker } & No & $22(3-41)$ & 0.03 & \multirow{2}{*}{1} & \multirow{2}{*}{1.0} \\
\hline & Yes & $21(-8-50)$ & 0.2 & & \\
\hline \multirow{2}{*}{$\begin{array}{l}\text { Duration of neck } \\
\text { pain (months) }\end{array}$} & $2-12$ & $38(16-59)$ & 0.001 & \multirow{2}{*}{29} & \multirow{2}{*}{0.07} \\
\hline & $>12$ & $9(-13-31)$ & 0.4 & & \\
\hline \multirow{2}{*}{$\begin{array}{l}\text { Duration of arm } \\
\text { pain } \\
\text { (months) }\end{array}$} & $2-12$ & $31(9-52)$ & 0.005 & \multirow{2}{*}{18} & \multirow{2}{*}{0.3} \\
\hline & $>12$ & $13(-16-42)$ & 0.4 & & \\
\hline \multirow{2}{*}{$\begin{array}{l}\text { Neck pain } \\
\text { intensity (VAS) }\end{array}$} & $0-49$ & $18(-2-37)$ & 0.07 & \multirow{2}{*}{6} & \multirow{2}{*}{0.7} \\
\hline & $50-100$ & $24(7-40)$ & 0.006 & & \\
\hline \multirow{2}{*}{$\begin{array}{l}\text { Arm pain intensity } \\
\text { (VAS) }\end{array}$} & $0-49$ & $13(-6-32)$ & 0.2 & \multirow{2}{*}{22} & \multirow{2}{*}{0.1} \\
\hline & $50-100$ & $35(13-56)$ & 0.002 & & \\
\hline \multirow{2}{*}{ Shoulder pain } & Never/occasionally & $33(-25-33)$ & 0.8 & \multirow{2}{*}{29} & \multirow{2}{*}{0.9} \\
\hline & Every day/ always & $4(15-52)$ & 0.001 & & \\
\hline \multirow{2}{*}{ Back pain } & Never/occasionally & $21(2-40)$ & 0.03 & \multirow{2}{*}{9} & \multirow{2}{*}{0.6} \\
\hline & Every day/ always & $12(-17-40)$ & 0.4 & & \\
\hline \multirow{2}{*}{ Headache } & Never/occasionally & $25(6-44)$ & 0.01 & \multirow{2}{*}{12} & \multirow{2}{*}{0.5} \\
\hline & Every day/ always & $13(-17-42)$ & 0.4 & & \\
\hline \multirow{2}{*}{ Hand numbness } & Never/occasionally & $7(-22-36)$ & 0.6 & \multirow{2}{*}{24} & \multirow{2}{*}{0.2} \\
\hline & Every day/ always & $31(12-50)$ & 0.002 & & \\
\hline & Never/occasionally & $7(-20-35)$ & 0.6 & & \\
\hline rana weakness & Every day/ always & $30(11-50)$ & 0.003 & 23 & 0.2 \\
\hline Type of disc & Soft & $\begin{array}{l}73(25- \\
121)\end{array}$ & 0.005 & 42 & 0.1 \\
\hline herniation & Bony/ combined & $31(6-57)$ & 0.02 & & \\
\hline
\end{tabular}




\begin{tabular}{|c|c|c|c|c|c|}
\hline \multirow{2}{*}{$\begin{array}{l}\text { Sleeping } \\
\text { problems }\end{array}$} & Never/occasionally & $34(12-55)$ & 0.003 & \multirow{2}{*}{26} & \multirow{2}{*}{0.1} \\
\hline & Every day/ always & $8(-14-31)$ & 0.5 & & \\
\hline \multirow{2}{*}{$\begin{array}{l}\text { Anxiety due to } \\
\text { neck/arm } \\
\text { problems }\end{array}$} & Never/occasionally & $12(-5-29)$ & 0.2 & \multirow{2}{*}{42} & \multirow{2}{*}{$0.02^{*}$} \\
\hline & Every day/ always & $54(23-84)$ & 0.001 & & \\
\hline \multirow{2}{*}{$\begin{array}{l}\text { Work } \\
\text { expectations }\end{array}$} & High & $24(0-47)$ & 0.05 & \multirow{2}{*}{3} & \multirow{2}{*}{0.9} \\
\hline & Low & $21(-3-46)$ & 0.08 & & \\
\hline \multirow{2}{*}{$\begin{array}{l}\text { Treatment } \\
\text { expectations }\end{array}$} & Fully recovered & $7(-16-30)$ & 0.6 & \multirow{2}{*}{19} & \multirow{2}{*}{0.3} \\
\hline & Relief/improved & $26(4-48)$ & 0.02 & & \\
\hline \multirow{2}{*}{ NDI at baseline } & $0-40 \%$ & $18(-3-38)$ & 0.09 & \multirow{2}{*}{6} & \multirow{2}{*}{0.7} \\
\hline & $41-100 \%$ & $24(1-46)$ & 0.04 & & \\
\hline \multirow{2}{*}{ Zung } & 0-16 (normal) & $-2(-37-34)$ & 0.9 & \multirow{2}{*}{28} & \multirow{2}{*}{0.2} \\
\hline & 17-69 (at risk) & $26(8-43)$ & 0.005 & & \\
\hline \multirow{2}{*}{ EQ-5D index } & $>0.5$ & $6(-14-26)$ & 0.6 & \multirow{2}{*}{36} & \multirow{2}{*}{$0.02^{*}$} \\
\hline & $<0.5$ & $42(19-65)$ & 0.001 & & \\
\hline \multirow{2}{*}{$\begin{array}{l}\text { EQ-VAS } \\
\text { (VAS 0-100) }\end{array}$} & $50-100$ & $21(0-41)$ & 0.05 & \multirow{2}{*}{5} & \multirow{2}{*}{0.8} \\
\hline & $0-49$ & $16(-8-40)$ & 0.2 & & \\
\hline \multirow{2}{*}{$\begin{array}{l}\text { Arm/neck pain } \\
\text { ratio } \\
\text { (VAS) }\end{array}$} & $\begin{array}{l}\text { Arm pain< neck } \\
\text { pain }\end{array}$ & $16(-5-36)$ & 0.1 & \multirow[t]{2}{*}{13} & \multirow[t]{2}{*}{0.4} \\
\hline & $\begin{array}{l}\text { Arm pain>neck } \\
\text { pain }\end{array}$ & $29(5-53)$ & 0.02 & & \\
\hline \multirow[b]{2}{*}{ SES } & $129-200$ & $12(-11-35)$ & 0.3 & \multirow[b]{2}{*}{17} & \multirow[b]{2}{*}{0.3} \\
\hline & $0-128$ & $29(7-51)$ & 0.01 & & \\
\hline \multirow{3}{*}{ DRAM } & Normal & $-2(-37-34)$ & 0.9 & & \multirow{3}{*}{0.4} \\
\hline & At risk & $24(3-45)$ & 0.03 & & \\
\hline & Distress & $26(-10-61)$ & 0.2 & & \\
\hline
\end{tabular}

Treatment effect (TE) is the mean change in the outcome parameter from baseline to12 months

Difference in TE between TEM groups was analyzed with two-way full-factorial ANOVA and difference in treatment effect compared to baseline was analyzed from the estimated marginal means of the same analysis.

*Significant difference between groups $(p<0.05)$ detected.

Abbreviations: NDI: Neck Disability Index; EQ-5D: EuroQol five dimensions; SES: Self Efficacy Scale; DRAM: Distress and Risk Assessment Method. 
Table 4

Treatment effects and group comparisons. Outcome: arm pain (VAS 0-100) at 12 months.

\begin{tabular}{|c|c|c|c|c|c|}
\hline $\begin{array}{l}\text { Treatment effect } \\
\text { modifier (TEM) }\end{array}$ & TEM groups & $\begin{array}{l}\text { Difference in } \\
\text { treatment } \\
\text { effect } \\
\text { surgery - } \\
\text { non-surgery } \\
(95 \% \mathrm{Cl})\end{array}$ & $\begin{array}{l}P \text { treatment } \\
\text { effect } \\
\text { surgery - } \\
\text { non-surgery }\end{array}$ & $\begin{array}{l}\text { Difference } \\
\text { in treatment } \\
\text { effect } \\
\text { between } \\
\text { TEM groups }\end{array}$ & $\begin{array}{l}P \text { between } \\
\text { TEM groups }\end{array}$ \\
\hline \multirow[t]{2}{*}{ Sex } & Male & $\begin{array}{l}-9(-29- \\
10)\end{array}$ & 0.3 & \multirow[t]{2}{*}{41} & \multirow[t]{2}{*}{$0.007^{*}$} \\
\hline & Female & $32(10-54)$ & 0.005 & & \\
\hline \multirow{2}{*}{ Age } & $18-47$ & $6(-16-28)$ & 0.6 & \multirow[b]{2}{*}{3} & \multirow{2}{*}{0.8} \\
\hline & $48-65$ & $9(-15-33)$ & 0.4 & & \\
\hline \multirow[b]{2}{*}{ Smoker } & No & $9(-10-27)$ & 0.4 & \multirow[b]{2}{*}{3} & \multirow{2}{*}{0.8} \\
\hline & Yes & $12(-18-42)$ & 0.4 & & \\
\hline \multirow{2}{*}{$\begin{array}{l}\text { Duration of neck } \\
\text { pain (months) }\end{array}$} & $2-12$ & $28(9-47)$ & 0.005 & \multirow[b]{2}{*}{39} & \multirow[b]{2}{*}{$0.007^{\star}$} \\
\hline & $>12$ & $-11(-30-9)$ & 0.3 & & \\
\hline \multirow[b]{2}{*}{$\begin{array}{l}\text { Duration of arm } \\
\text { pain } \\
\text { (months) }\end{array}$} & $2-12$ & $24(5-43)$ & 0.02 & \multirow[b]{2}{*}{42} & \multirow[b]{2}{*}{$0.01^{*}$} \\
\hline & $>12$ & $-18(-45-8)$ & 0.2 & & \\
\hline \multirow{2}{*}{$\begin{array}{l}\text { Neck pain } \\
\text { intensity (VAS) }\end{array}$} & $0-49$ & $2(-22-26)$ & 0.9 & \multirow{2}{*}{13} & \multirow{2}{*}{0.4} \\
\hline & $50-100$ & $15(-5-36)$ & 0.2 & & \\
\hline \multirow{2}{*}{$\begin{array}{l}\text { Arm pain intensity } \\
\text { (VAS) }\end{array}$} & $0-49$ & $3(-14-20)$ & 0.7 & \multirow{2}{*}{17} & \multirow{2}{*}{0.2} \\
\hline & $50-100$ & $20(-1-40)$ & 0.04 & & \\
\hline \multirow{2}{*}{ Shoulder pain } & Never/occasionally & $-8(-37-20)$ & 0.6 & \multirow{2}{*}{30} & \multirow{2}{*}{0.09} \\
\hline & Every day/ always & $22(3-40)$ & 0.03 & & \\
\hline \multirow{2}{*}{ Back pain } & Never/occasionally & $8(-11-28)$ & 0.4 & \multirow{2}{*}{1} & \multirow{2}{*}{0.9} \\
\hline & Every day/ always & $7(-23-37)$ & 0.6 & & \\
\hline \multirow{2}{*}{ Headache } & Never/occasionally & $1(-18-19)$ & 1.0 & \multirow{2}{*}{35} & \multirow{2}{*}{0.05} \\
\hline & Every day/ always & $36(6-66)$ & 0.02 & & \\
\hline \multirow[t]{2}{*}{ Hand numbness } & Never/occasionally & $\begin{array}{l}-15(-45- \\
14)\end{array}$ & 0.3 & \multirow[t]{2}{*}{34} & \multirow[t]{2}{*}{0.05} \\
\hline & Every day/ always & $19(1-37)$ & 0.04 & & \\
\hline & Never/occasionally & $-5(-33-22)$ & 0.7 & & \\
\hline Hand weakness & Every day/ always & $16(-4-36)$ & 0.1 & 21 & 0.2 \\
\hline & Soft & $36(-12-83)$ & 0.1 & & \\
\hline
\end{tabular}




\begin{tabular}{|c|c|c|c|c|c|}
\hline $\begin{array}{l}\text { Type of disc } \\
\text { herniation }\end{array}$ & Bony/ combined & $16(-8-40)$ & 0.2 & 20 & 0.5 \\
\hline \multirow{2}{*}{$\begin{array}{l}\text { Sleeping } \\
\text { problems }\end{array}$} & Never/occasionally & $16(-5-38)$ & 0.1 & \multirow{2}{*}{14} & \multirow{2}{*}{0.4} \\
\hline & Every day/ always & $2(-20-24)$ & 0.8 & & \\
\hline \multirow{2}{*}{$\begin{array}{l}\text { Anxiety due to } \\
\text { neck/arm } \\
\text { problems }\end{array}$} & Never/occasionally & $6(-12-25)$ & 0.5 & \multirow{2}{*}{15} & \multirow{2}{*}{0.4} \\
\hline & Every day/ always & $21(-10-52)$ & 0.2 & & \\
\hline \multirow{2}{*}{$\begin{array}{l}\text { Work } \\
\text { expectations }\end{array}$} & High & $7(-16-31)$ & 0.6 & \multirow{2}{*}{9} & \multirow{2}{*}{0.6} \\
\hline & Low & $16(-9-42)$ & 0.2 & & \\
\hline \multirow{2}{*}{$\begin{array}{l}\text { Treatment } \\
\text { expectations }\end{array}$} & Fully recovered & $-3(-26-20)$ & 0.8 & \multirow{2}{*}{11} & \multirow{2}{*}{0.5} \\
\hline & Relief/improved & $8(-13-28)$ & 0.5 & & \\
\hline \multirow{2}{*}{ NDI at baseline } & $0-40 \%$ & $4(-16-24)$ & 0.7 & \multirow{2}{*}{8} & \multirow{2}{*}{0.6} \\
\hline & $41-100 \%$ & $12(-11-36)$ & 0.3 & & \\
\hline \multirow[t]{2}{*}{ Zung } & 0-16 (normal) & $\begin{array}{l}-14(-49- \\
22)\end{array}$ & 0.4 & \multirow[t]{2}{*}{29} & \multirow[t]{2}{*}{0.2} \\
\hline & 17-69 (at risk) & $15(-2-33)$ & 0.09 & & \\
\hline \multirow{2}{*}{ EQ-5D index } & $>0.5$ & $2(-18-22)$ & 0.8 & \multirow{2}{*}{19} & \multirow{2}{*}{0.2} \\
\hline & $<0.5$ & $21(-4-47)$ & 0.09 & & \\
\hline \multirow{2}{*}{$\begin{array}{l}\text { EQ-VAS } \\
\text { (VAS 0-100) }\end{array}$} & $50-100$ & $-1(-22-20)$ & 0.9 & \multirow{2}{*}{21} & \multirow{2}{*}{0.2} \\
\hline & $0-49$ & $20(-5-44)$ & 0.1 & & \\
\hline \multirow{2}{*}{$\begin{array}{l}\text { Arm/neck pain } \\
\text { ratio } \\
\text { (VAS) }\end{array}$} & $\begin{array}{l}\text { Arm pain }<\text { neck } \\
\text { pain }\end{array}$ & $12(-8-33)$ & 0.2 & \multirow[t]{2}{*}{3} & \multirow[t]{2}{*}{0.9} \\
\hline & $\begin{array}{l}\text { Arm pain> neck } \\
\text { pain }\end{array}$ & $9(-15-33)$ & 0.5 & & \\
\hline \multirow{2}{*}{ SES } & $129-200$ & $-1(-24-21)$ & 0.9 & \multirow{2}{*}{21} & \multirow{2}{*}{0.2} \\
\hline & $0-128$ & $20(-2-41)$ & 0.08 & & \\
\hline \multirow[t]{3}{*}{ DRAM } & Normal & $\begin{array}{l}-14(-49- \\
22)\end{array}$ & 0.4 & & \multirow[t]{3}{*}{0.2} \\
\hline & At risk & $11(-10-31)$ & 0.3 & & \\
\hline & Distress & $36(-1-72)$ & 0.06 & & \\
\hline
\end{tabular}

Treatment effect (TE) is the mean change in the outcome parameter from baseline to12 months

Difference in TE between TEM groups was analyzed with two-way full-factorial ANOVA and difference in treatment effect compared to baseline was analyzed from the estimated marginal means of the same analysis.

* Significant difference between groups $(p<0.05)$ detected.

Abbreviations: NDI: Neck Disability Index; EQ-5D: EuroQol five dimensions; SES:

Self Efficacy Scale; DRAM: Distress and Risk Assessment Method. 
